\title{
植物群落中物种小尺度空间结构研究
}

\author{
刘振国 1,2 李镇清 ${ }^{1 *}$ \\ （1 中国科学院植物研究所植被数量生态学重点实验室, 北京 100093）（2 中国科学院研究生院, 北京 100039）
}

摘 要 植物群落中, 物种小尺度空间结构影响着种群或群落的动态及有关的生态学过程。植物主要是和它同种 或异种的邻近个体相互作用, 植物个体周围的局部环境和大空间尺度下群落的平均水平是完全不同的。群落中的 许多过程都影响小尺度空间结构的形成和动态, 同样, 局部空间结构反过来影响着植物的生长、更新和调亡等重要 过程。鉴于目前对小尺度空间结构进行的大量研究以及其重要性, 有必要对其研究进展进行适当的总结, 以期明 确将来进一步的研究方向。该文以此为出发点, 首先介绍了植物群落中物种小尺度空间结构产生的 6 个原因: 1) 生境的空间异质性;2)植物繁殖体的传播; 3)植物之间的相互作用;4)生物环境(动物和微生物)的作用;5)外界干扰 的作用;6)多因子综合作用。然后阐述了小尺度空间结构意义及对生物多样性、植物种群遗传学和恢复生态学研 究的影响。最后对目前物种小尺度空间结构研究存在的几点问题及将来的研究方向作以下归纳: 1)大尺度植被动 态的研究应该整合小尺度空间结构的信息;2)不论从生物学还是生态学上来讲, 植被小尺度空间结构的研究应该 把植物作为中心, 确定适当的尺度和采取合理的空间统计方法; 3) 充分重视小尺度空间结构在退化生态系统恢复 中的应用意义;4)注重从小尺度的局部格局研究入手对群落总体特征进行整合;5)植物群落动态研究中,物种小尺 度空间结构与平均场假说相结合的必要性。

关键词 植物物种 小尺度 空间结构 平均场假说

\section{PERSPECTIVES ON SMALL-SCALE SPATIAL STRUCTURE OF PLANT SPECIES IN PLANT COMMUNITIES}

\author{
LIU Zhen-Guo ${ }^{1,2}$ and LI Zhen-Qing ${ }^{*}$ \\ (1 Laboratory of Quantitative Vegetation Ecology, Institute of Botany, Chinese Academy of Sciences, Beijing 100093, China)
}

(2 Graduate School of Chinese Academy of Sciences, Beijing 100039, China)

\begin{abstract}
Small-scale spatial structure of plant species is important in plant ecology as it affects the dynamics of plant populations, communities and ecosystem processes. Plants interact primarily with their immediate neighbors, and the view of the community as seen by an individual plant can be quite different from processes averaged over large spatial scales. Many processes influence the formation and dynamics of small-scale spatial structures of plant species, and local spatial structure in turn has an effect on the vital processes of plant growth, birth and death. This paper summarizes developments in this area of research based on the extensive literature on small-scale spatial structure of plant species to help direct further research efforts. Firstly, this paper introduces six factors that lead to the formation of small-scale spatial structure of plant species, including 1) habitat spatial heterogeneity, 2) dispersal of propagules, 3) interactions between plants, 4) effects of the biological environment (animals and microbes), 5) effects of exoteric disturbances, and 6) the integrated effects of many factors. The significance and effects of small-scale spatial structure on studies of biological diversity, plant population genetics and restoration ecology are then examined. Finally, several questions were raised and a list of suggested areas of future research on this topic were presented that included: 1) Information on small-scale spatial structure should be integrated into vegetation dynamics at large scales; 2) Either biologically or ecologically, the research about small-scale spatial structure of vegetation should focus on plants, make certain the adequate scale and adopt correct spatial statistical methods; 3) The practical implications of smallscale spatial structure for degraded ecosystems should be highly taken into account; 4) Integration of whole community characteristics should begin with local patterns on small scales; and 5) Small-scale spatial structure should be combined with traditional mean-field theory in order to deeply explore plant community dynamics.
\end{abstract}

Key words Plant species, Small scale, Spatial structure, Mean-field assumption 
空间结构一般指某个等级水平的生态学系统 (种群、群落或景观) 中大小和形状不同的组成单元 (斑块)在空间上的排列。它是各种生态学过程 (如 干扰、竞争)在不同尺度上综合作用的结果(肖笃宁 等, 1997)。同时, 空间结构对群落中有关过程的发 生以及种群、群落动态都具有重要的影响。例如, Rees 等 (1996)对沙丘一年生植物进行了 10 年的研 究, 结果发现种内聚集减少了种群的大小, 并且小尺 度种间分离导致了种间竞争的消失; Stoll 和 Prati (2001) 在实验中发现处于竞争劣势的一年生植物, 聚集分布比随机分布具有较高的生物量。

格局和尺度的概念无疑是相互缠绕在一起的。 格局的描述是变化的描述,而且变化的定量描述必 须有确定尺度, 因此格局的识别是尺度辩识的开始 （Levin, 1992）。实际上, 植物个体是在一个特定的 空间尺度范围内 (邻域)感受其周围环境(生物和非 生物)。这样的邻域也许很小, 例如, Mack 和 Harper (1977)对 4 种沙地一年生植物的研究发现植物的重 量和结实率取决于以其为圆心 $2 \mathrm{~cm}$ 为半径的圆内 的邻体; Silander 和 Pacala (1985) 指出 $5 \mathrm{~cm}$ 半径的圆 给出了 Arabidopsis thaliana 个体竞争模型的最好拟 合。正是因为这样的局部相互作用,仅仅几厘米尺 度上的空间结构可能影响种群水平的行为, 而与较 大尺度上的空间结构也许是不相关的 (Molofsky, 1999）。相对来说，小尺度空间结构的调查数据能更 准确地从生物学背景上提供和解释植物个体周围的 局部空间结构,而要研究种群大的空间结构时,大的 尺度可能要准确一些( Purves \& Law，2002)。

小尺度空间结构的研究是 Stowe 和 Wade( 1979) 提出的, 对草地群落而言, 它是研究几厘米内的格局 规模、种间关系以及环境因子的作用等。植物群落 中, 植物主要是和它同种 (Intraspecific) 或异种 (Interspecific) 的邻近个体 (Immediate neighbours) 相互作用, 邻居植物 (Neighbour plant) 对目标植物（Target plant） 的影响不论是在地上还是在地下都是明显存在的: 在地上, 邻居植物通过对目标植物个体的遮荫来影 响目标植物对光资源的获取; 在地下, 邻居植物通过 改变自身根系的不同配置格局来影响目标植物对养 分和水分的吸收。相反, 目标植物所能感受到的局 部范围之外的个体相对来说对这些过程的影响不 大, 因此, 物种在某一大空间尺度上的平均密度 (即 所谓的平均场假说 (Mean-field assumption))( Law et $a l ., 2000)$, 对小尺度下有关过程的影响很小 (Mack \& Harper, 1977)。
虽然在植物生态的早期研究中已经认识到植物 然落具有空间结构 (Blackman, 1935), 但是, 把植物 个体周围的局部景观 (Plant's-eye view) 引进到群落 的动态系统中是最近才发展起来的。鉴于目前对小 尺度空间结构进行的大量研究以及其重要性, 有必 要对其研究进展进行适当的总结, 以期明确将来进 一步研究的方向。本文以此为出发点, 概括介绍了 植物群落中的物种小尺度空间结构产生的原因以及 小尺度空间结构的意义及影响, 最后提出了目前物 种小尺度空间结构研究的几点问题与展望。

\section{1 引起物种小尺度空间结构的原因}

引起物种小尺度空间结构的因素有很多, 总起 来说共有 6 个因素有助于物种小尺度空间结构的形 成。

\section{1 生境的空间异质性}

生境的空间异质性是生态系统的一个普遍特征 （Fowler，1988）, 是生物生境的一个基本属性。生境 的异质性不仅在大的空间尺度 (如生物群区、景观、 生态系统等)上明显地存在, 而且, 在小尺度(如个 体、构件等)上也能被探测到 (Fowler，1988; Jackson \& Caldwell, 1993)。在小的空间尺度上, 植物维持、 生长和繁衍所必须的资源是异质性分布的 (Frankland et al., 1963; Kelly \& Canham, 1992; Hutchings \& Price, 1993; Baldocci \& Collineau, 1994)。植物种的 分布在一定程度下取决于生境资源的时空分布格 局。生境资源的斑块化决定了资源的可利用程度, 并控制位于其上的植物种对资源的利用方式, 进而 决定了植物种的斑块化分布格局。另外, 许多生态 学过程(如干扰)最终都是通过改变异质生境中的资 源可利用性来影响物种的小尺度空间分布的 ( de Blois et al ., 2002)。

Thiery 等(1995)论述了植被在小尺度上呈“虎皮 状( Tiger bush)”分布格局是由地形的坡向和坡度形 成的。沈泽吴(2002) 分析了亚热带山地森林样带植 被在不同生境因子(地形特征、土壤、光照等)影响下 的多尺度上的水平格局, 结果表明,地形特征指标与 许多所谓的“直接”的生境因子, 如土壤理化属性指 标, 和林冠空隙等植物群落的结构因子有着密切的 相关性。并且随着尺度增大, 生境的小尺度异质性 被平滑掉, 诸因子之间的相关显著性逐渐降低。这 为解释生态过程的强度与速率提供了重要的依据。 同时,地形指标在反映生境异质性上有着突出的表 现力, 明显体现了地形对生境条件的“综合性指示” 
能力。谢佳彦和邓志平 (2003) 对杭州五云山米槠 (Castanopsis carlesii) 种群幼苗的空间分布格局研究 表明, 生境的异质性导致适应特定生境的米槠幼苗 在小尺度上呈斑块状分布。沈泽吴等(2000)对三峡 大老岭森林物种多样性的空间格局分析表明, 植被 的物种多样性存在小尺度上的强烈异质性, 小地形 (坡度、坡位、海拔)差异带来的影响占有突出地位, 而坡度、坡位的差异主要与举不胜举的光照、温度/ 湿度、土壤厚度与结构, 以及林窗干扰的发生概率相 联系。

在气候条件一致的情况下, 土壤理化性状的空 间异质性决定了小尺度上植被空间分布的差异 (钱 亦兵等, 2004)。例如, 干旱区土壤资源广泛存在着 空间异质性 (Jonathan et al ., 2002), 并且干旱和半干 旱地区在荒漠化的过程中, 荒漠灌丛的入侵最终形 成能指示荒漠特征的“肥料岛” (Garner \& Steinberger, 1989; Schlesinger et al., 1990, 1996; Kieft et al., 1998)。同时, 土壤资源空间异质化增强 (Schlesinger et al., 1996), 小尺度空间上的植被斑块化程度相应 增大。

\section{2 植物繁殖体的传播}

植物通过繁殖体的传播来占据新的空间生态 位, 由此改变群落中物种的空间结构。大多数靠种 子繁殖的植物其种子都落在其母体的附近 ( Harper, 1977), 但是种子偶尔的被动传播在一定程度上破坏 了物种聚集分布的形成, 诸如偶然的阵风能使种子 的传播距离比较远 (van Dorp et al., 1996), 而通过 动物传播的种子能分散到更远的距离 ( Isagi et al., 2000; Ennos, 2001)。Silvertown 和 Law (1987) 指出由 于植物种子散布的空间局限性使植物物种的共存也 可由聚集分布促成。谢佳彦和邓志平(2003)对杭州 五云山米楮种群幼苗、操国兴等(2003)对缙云山川 鄂连荵茶 (Camellia rosthorniana)、苏志尧等(2000)对 粤北天然林内优势植物一一荷 ( Schima superba)、 栲树 (Castanopsis fargesii) 的种群空间格局的研究都 表明, 被研究植物种子的散布特性(果实以重力传播 为主, 成熟果实和种子都集中在母树周围呈斑块状 分布) 决定了它们在小尺度上的集群分布。荒漠植 物种子可凭借无远距离传播适应、重量大等机制降 低位移、在母株周围分布以维持对最佳生境的侵占 (刘志民等, 2002), 形成小尺度空间上聚集分布。这 种聚集种子繁殖单元 (Synaptospermy) 的形成具有保 护种子不受捕食和其它危险的作用。

对于靠无性系繁殖的植物, 其根状茎、匍匐茎等
繁殖器官产生无性系分株的过程就决定了小尺度上 的斑块化分布。黄志伟等(2001)对青海湖 4 种主要 湿地植物的种群分布格局及动态的研究表明, 克隆 植物以基株产生无性系分株在空间拓展的过程, 使 种群的空间结构由原来的随机分布变为聚集分布。

\section{3 植物之间的相互作用}

植物个体之间的竞争、促进等相互作用在某些 条件下也有助于物种小尺度空间结构的形成 (Stoll \& Weiner, 2000)。邻近植物能以各种方式来改善目 标植物个体周围的生长条件, 包括极端环境条件的 改善( Brooker \& Callaghan, 1998), 诸如在干旱环境中 的高度暴晒 (Holzapfel \& Mahall, 1999) 以及在亚北极 区苔原中的极端寒冷条件 (Carlsson \& Callaghan, 1991)。这方面的研究已发展到用模型来定量化研 究的阶段, 如邻居模型和局域影响模型。这些模型 利用植物的直接环境 (Plant's immediate environment) 和局部邻居结构的信息设计种群的动态。邻居模型 假设植物个体之间的大小差异可以用邻居植物的大 小、相似程度和角度分散来解释 (Weiner, 1985; Silander \& Pacala, 1985), 而局域影响模型把植物的大 小等同于它所能影响的周围区域的大小, 当植物生 长时, 不同植物所能影响的区带 (Zone) 相遇, 结果导 致在重叠的面积上竞争作用的发生。竞争作用可能 是对称的, 但是如果最大的植物得到了一部分相当 大的资源, 那竞争就是不对称的 (Weiner, 1990)。

\section{4 生物环境(动物和微生物)的作用}

生物环境在一定程度上也影响小尺度空间结 构, 但是, 它不像非生物环境那样, 趋向于被固定在 植物群落动态的时间尺度上, 而是生物环境自己具 有一个随着时间改变的空间结构。比较典型的就是 许多寄主病原体, 它的存在能使靠近母体植物的幼 苗死亡 ( Augspurger, 1984; Packer \& Clay, 2000), 从 而阻止了寄主种群局部聚集的形成, 这潜在地妨碍 了某一种植物在群落中占据优势地位。

\section{5 外界干扰的作用}

外界干扰能改变生境中的资源环境, 扭转原有 的生态过程, 重建生态格局。干扰具有作用上的相 对性和一定的尺度性。

Kellner 和 Bosch (1992) 认为半干旱草地植被的 空间格局是由食草动物的选择性采食造成的。 Bromley 等( 1997) 认为植物斑块的形成是由放牧和 火烧等因素形成的。陈鹏等 (2003) 对天山的绿洲荒漠过渡带景观的植被与土壤特征要素进行了空间 异质性分析, 结果表明植被小尺度上变异的主要原 
因是小尺度人为干扰(过度放牧、开垦、樵采)局部因 素和过程造成地表裸露度增加引起的。刘振国和李 镇清 (2004, 2005 ) 研究了不同放牧强度下冷蒿 (Artemisia frigida)和糙隐子草(Cleistogenes squarrosa) 种群的小尺度空间结构, 指出放牧确实影响冷蒿和 䊁隐子草在不同群落中的小尺度空间结构。

自然森林生态系统中, 由于包括树木自身的衰 老、病虫害, 来自外部的风力、雷电、雪压, 以及人为 砍伐等因素的单独或综合干扰, 使得连续的群落冠 层出现空间上镶嵌的斑块状空隙(李贵才等, 2003), 从而形成小尺度的林窗 (Gap), 其具有不同于林内的 独特小气候, 如光照充足, 气温和地温较高等 (Abe et al., 1995; Barik et al., 1992)。林窗的形成与恢 复, 导致了新的异质性生境和各个处于不同发育阶 段的群落斑块形成。林窗是森林更新与演替中的重 要因素与驱动因子(李贵才等, 2003)。

天然放牧草地中, 草地微斑块( 小尺度空间格局 的具体体现)的形成与草地退化过程有着相同的推 动力, 这种作用力主要来自于放牧压力和草地鼠类 活动两种外界干扰。张卫国等(2003)研究了不同放 牧强度干扰下高寒草甸草原群落中斑块的形成机制 及其性状、格局的变化, 结果表明: 在轻、中、重度 3 个草地退化梯度下, 草地微斑块的种类和数量表现 为先随退化程度增加而上升, 达到中度退化后又转 化为随退化程度增加而下降的趋势。与此同时, 斑 块总面积和个体面积则表现为随退化程度增加而上 升的趋势。斑块植被的组成、盖度、高度和地上生物 量等性状指标总的变化趋势是随退化程度的加剧而 下降, 但不同类型的斑块在下降时段、下降幅度和格 局上存在较大差异。斑块的多样性指数、均匀度指 数与放牧强度呈正相关, 而破碎度和优势度则表现 为负相关。

\section{6 多因子综合作用}

实际上, 植物群落中的物种小尺度空间结构并 不只是在一种影响因素作用下形成的, 而是在一种 因子起主导作用、几种影响因素共同作用的结果, 即 物种小尺度空间结构决定于被研究物种本身的生物 学特性和环境条件两方面及其相互作用, 是由种群 特性、种间关系和环境条件的综合作用所决定的。 Jeltsch 等(1997)认为植物的分布格局是由竞争、克 隆生长和放牧或火烧引起的植被生活型的改变等多 种因子相互影响产生的。辛晓平等(2000)对放牧和 围封条件下羊草( Leymus chinensis) 碱化草地中斑块 分布格局的研究表明, 不存在放牧干扰时, 土壤过程
是影响斑块分布格局的主要因素, 但较小尺度上羊 草的生长扩散能力也是很重要的生态学过程。存在 放牧干扰时, 小尺度斑块往往是严重干扰的结果, 起 主导作用的生态学过程是土壤条件(突然恶化和极 度破损化) 的限制, 放牧干扰不再是主要生态学过 程,干扰在较大尺度空间格局中更重要。

\section{2 物种小尺度空间格局的意义及影响}

物种小尺度空间结构动态的意义是深远的。通 过比较 logistic 方程的空间 (具有复杂反馈作用) 和 非空间形式 (非常简单) 可以看出, 用一个非空间的 模型来解决一个具有空间结构的过程是行不通的。 自然植物群落的动态也取决于小尺度上的空间结 构。例如, 沙丘环境中, 一年生植物同种个体的集聚 和异种个体的分散大大加剧了种内竞争的强度, 相 反却减弱了种间竞争的强度 (Rees et al., 1996); 草 本植物的同种个体的集聚能促进竞争能力比较弱的 物种维持生存 (Stoll \& Prati, 2001)。在空间结构不 明显或者个体之间发生竞争等相互作用的距离很大 的情形下, 非空间模型可以较好地模拟现实的生态 学过程。例如, Pacala 和 Silander (1990) 研究两种具 有相对较弱空间结构的一年生野草时, 非空间模型 就模拟的很好。

\section{1 对生物多样性研究的影响}

群落物种多样性的维持机制是生物多样性研究 的重要科学问题。任何群落的物种多样性都是矛盾 双方的平衡统一。一方面较小尺度上的非生物过 程、种间关系和一些偶然事件趋向降低多样性; 另一 方面来自其它群落的物种迁移等趋向于增加多样 性。尽管对其机制还不完全清楚, 但大量的证据已 经说明较小尺度上(局部)的生态过程严重影响着共 存物种的数量 (叶万辉, 2000)。杨利民等(2002)对 松嫩平原的一个多样性较高的羊草-杂类草草甸群 落内物种分布格局的研究结果表明, 群落中多数 $(72 \%$ ) 物种为聚集分布, 其格局尺度多小于 $0.04 \mathrm{~m}$, 并认为物种聚集分布可能在维持多样性中起重要作 用, 并在群落物种花期分布、物种实现生态位、种间 关联与种间协变研究的基础上, 提出了草地群落物 种多样性维持机制的小尺度格局竞争假说: 1) 草地 群落中的物种, 绝大多数在利用养分和水分资源方 面是相似的, 因此, 它们的生态位高度重叠而不是分 化(杨利民等, 2001);2)物种花期分布呈随机或聚集 分布, 花期分化不明显(杨利民等, 2000); 3) 在相对 均质的生境中植物物种的共存取决于多数植物的聚 
集型分布的生物学特性, 而环境因素更多地是在群 落物种选择中起决定作用; 4) 物种通过聚集性分布 争夺生存空间, 在小尺度上发生竞争排斥, 并随尺度 增大而减弱; 5) 由于植物个体的生理和生态学寿命 有限, 当一个或多个植物个体死亡后, 为其它物种或 个体侵入提供机会, 就像抽彩式竞争, 先定居者获 胜。因此, 群落中的物种格局是动态的、波动的, 新 物种格局的形成具有随机性; 6)环境因子的波动对 多数物种来说, 可能是均等的, 即它们的种群数量都 可能增加, 也都可能减少。总之, 小尺度空间格局的 确影响着群落的物种多样性, 对于它的研究有助于 揭示群落内物种共存的维持机制。

\section{2 对植物种群遗传学研究的影响}

较小尺度上的空间结构对植物种群遗传学具有 重要的意义。从广义上来说, 这依赖于种群遗传学 的结果对平均场假说的依赖程度。小尺度空间结构 对植物种群遗传学具有 3 方面的影响:

\subsection{1 有助于突变种的成功入侵}

在一个种子散布受限制的具有空间结构的生态 系统中, 携带有突变基因的变种个体会表现出成丛 化的集聚分布, 突变种个体作为邻居的频率就会远 远大于突变种在种群中的平均频率。这样, 突变种 的最初生长并不单独由其平均频率的动态决定, 它 也依赖于当地种和突变种在较小尺度上的空间结 构。考虑到空间结构的入侵标准, 较小尺度上的空 间结构既可以用于离散的空间网格 (van Baalen \& Rand, 1998; Ferrière \& Le Galliard, 2000), 也可以用 于连续空间(Bolker \& Pacala, 1999)。这些研究明显 指出小尺度空间结构能改变由依赖突变种增加速率 的种群遗传学中得来的结果, 例如受保护的多态现 象和进化稳定对策 (Evolutionarily stable strategy, ESS)。

\subsection{2 有助于遗传多态现象的维持}

异质性的非生物环境自身具有一定的空间结 构, 加上植物本身具有的非运动性, 这都允许植物的 遗传多态现象的存在 (Levene, 1953)。具有菼光性 的假单胞菌 (Pseudomonas fluorescens) 开始只有一种 基因型。运动能力差的类群在 3 天之内呈现多态现 象, 并且和主要的表现型类群呈现出空间分离状态, 而那些运动能力强的类群仍然保持着单态现象 （Rainey \& Travasion, 1998)。由生物过程产生的小尺 度空间结构进一步增加了遗传多态现象存在的可 能。在一个具有空间集聚格局的种群中, 距离小的 邻居之间的竞争可能强烈地排斥普通的母性祖先的

\section{基因 (Kalisz et al ., 1999)。}

\subsection{3 有助于散布能力的进化}

植物表现型的许多特点( 包括植物的生长型、花 序的大小以及花粉和种子的散布机制)对它自身繁 殖体的传播有重要的影响, 这些特点的遗传变化很 早就有研究 (Aston \& Bradshaw, 1966)。携带有稀有 基因的植物的繁殖成功与否很可能受到它们自身产 生的小尺度空间结构的影响 (van Baalen \& Rand, 1998; Ferrière \& Le Galliard, 2000)。携带着低散布 能力基因的个体比携带着高散布能力基因的个体成 从化的程度要高, 从而影响它们的邻居个体也倾向 于携带低散布能力的基因。Hamilton 和 May (1977) 用一个示意性的模型来说明植物的散布优势。另一 方面, 在一个适于生长呈斑块化分布的空间异质性 环境中, 植物所具有的弱的散布能力可以认为是一 种积极的资本 (Bolker \& Pacala, 1999)。不包含小尺 度空间结构的散布进化模型会起误导作用。

\section{3 对恢复生态学研究的影响}

植物群落中小尺度空间结构最好的体现是群落 中微斑块的大量存在。草地植物群落中微斑块的大 量存在是天然放牧型草地最基本的特征之一。并且 草地微斑块是草地退化程度的一个重要表征 (王国 宏等, 2001), 因此草地微斑块所携带的信息可以作 为实施草地管理的重要依据。

张卫国等(2003)在剖析了高寒草甸草原中微斑 块的组成、结构和功能及多样性格局与草地退化程 度间的内在关系的基础上, 对草地微斑块的成因、草 地微斑块相关指标在确认草地退化程度上的应用、 利用微斑块的有关信息实施退化草地的恢复及更好 的管理等问题提出了讨论性的意见。这对于深刻认 识草地退化演替的本质、规范人类的活动, 指导草地 管理和改良实践、维护草地生产力和生态功能的可 持续发展具有重要的意义。陈玉福等(2000)在对毛 乌素沙化草地沙生半灌木群落植被盖度的空间变异 特点分析后, 指出认识植被盖度的空间变异特点有 助于理解荒漠化机制和制定有效的荒漠化防治措 施, 并强调要防止荒漠化过程, 就必须保护所有尺度 上的斑块, 特别要注意小尺度斑块的保护, 因为长期 的过度放牧可能会破坏这些小尺度斑块。

\section{3 问题与展望}

虽然到目前为止, 植物生态学家已开展了大量 有关物种小尺度空间结构的研究, 但是小尺度空间 结构的研究还存在许多问题需要解决。下面我们就 
对目前小尺度空间结构存在的几点问题及将来的研 究方向作如下归纳:

1)大尺度植被动态的研究应该整合小尺度空间 结构的信息。目前, 生态学家利用遥感、地理信息系 统等先进手段进行景观或者全球大尺度植被动态的 研究越来越多, 而这些研究对小尺度上的细节问题 考虑的甚少或者根本没有考虑, 这时如果结合小尺 度空间结构研究得到的有关信息, 则对全球变化背 景下植被变化动态问题的研究会更加透彻。因此, 小尺度空间结构的研究作为对大尺度上植被动态研 究的补充, 可以有效地弥补大尺度研究中的缺陷。

2)不论从生物学还是生态学上来讲, 植被小尺 度空间结构的研究应该把植物作为中心, 确定适当 的尺度和采取合理的空间统计方法。由于草原群落 结构比森林群落结构简单的多, 所以关于空间格局 和过程的研究大多数是在草原上进行的。在草原群 落中, 关于植被小尺度空间结构的研究也已经做了 大量的研究 (Kershaw \& Looney, 1985; Greig-Smith, 1987; Krahulec et al., 1990)。但是, 关于小尺度空 间结构的研究依然存在两个问题需要解决: 一是关 于草原群落中空间结构的调查尺度通常比植物个体 之间相互作用的尺度要大, 以前关于小尺度空间结 构研究中的取样单元几乎都大于 $0.01 \mathrm{~m}^{2}(10 \mathrm{~cm} \times$ $10 \mathrm{~cm}$ ); 二是以前研究中经常使用的空间统计学方 法(包括 Block-quadrat variance, Variance-to-mean ratio 以及 Two-term local variance) 虽然在描述植被格局中 有很大的用处, 并且能揭示在哪些尺度下空间结构 是最明显的, 但都不能代表植物个体的局部景观 (Purves \& Law，2002)。在尺度合适的研究中, 只有 Mahdi 和 Law (1987) 的简单局部密度测量 (Simple local density measurements)、van Rijnberk 和 Duing (1990)的相关图 (Correlograms)、Purves 和 Law (2002) 的空间协方差函数 (Spatial covariance functions) 和 van der Hoeven 等 (1990) 的具有时滞的 Moran's I 函数 (Lagged Moran's I functions) 能以植物为中心来解释 小尺度的植被格局。今后的研究方法应该逐渐克服 以上的两个问题, 并把以植物为中心的解释方式放 在首位来研究植被的小尺度空间结构, 只有这样从 生物学和生态学上来讲才更有意义。

3) 充分重视小尺度空间结构在退化生态系统恢 复中的应用意义。作为草地群落中小尺度空间结构 最好的体现, 草地微斑块的组成、性状和格局在一定 程度上反映了草地现时演替阶段、草地演替的驱动 力及其演替趋势, 因而对于认知和确定草地的退化
程度具有重要的意义。对于草地退化程度的认定, 现行的样方测度法是有缺陷的, 如果所设样方数达 不到足够大, 结果很容易对草地状况作出背离实际 的判断 (Stohlgren, 1998)。因为, 草地中各类斑块的 植被性状差异很大, 分布带有随机性, 斑块在草地中 所占比例也不尽相同, 所以样方的信息很难避免为 某类或某几类斑块所左右。另外, 样方所提供的信 息在确认草地演替的原动力及其运行方向上也极为 有限。因此, 若能将草地微斑块的综合测度结果作 为确定草地性质及其退化程度的依据, 其全面性、准 确性和预测性显然要优于样方法(张卫国等, 2003)。

4）注重从小尺度的局部格局研究入手对群落 总体特征进行整合。生态系统的等级斑块层次结构 特点对于理解生态系统的结构与功能具有十分重要 的意义。根据等级斑块动态理论的兼容 (Incorporation)机制和复合稳定性(Metastability) (Levin, 1992), 要了解生态系统的自然格局与过程, 必须首先注重 尺度问题。由于高等级层次的生态学过程往往是大 尺度、低频率、慢速度的, 而低等级层次的过程则表 现为小尺度、高频率、快速度的, 这样自然植物群落 在相对较小的时间尺度上常表现为总体稳定, 而局 部变化的特点。因此, 要了解群落现时的组织过程 与格局形成机制, 必须通过对局部尺度、低等级层次 的群落斑块过程进行研究, 进而总结出群落水平的 总体特征 (叶万辉, 2000)。要注重从局部尺度的斑 块研究入手对总体特征进行整合, 而不是将局部过 程进行简单叠加。

5)植物群落动态研究中, 小尺度空间结构与平 均场假说相结合的必要性。由于竞争和促进作用通 常发生在短距离内, 所以局部小尺度空间结构肯定 会影响群落中植物种群的有关过程, 进而影响这个 种群的动态以及所在群落的动态。更准确的说, 不 论是从定性还是从定量的角度来看, 群落的动态并 不像平均场假说所描述的那样。平均场假说是指植 物遇到同种及异种个体的概率和它们在所占据的空 间中的平均密度成正比。Purves 和 Law (2002) 指出 平均场假设只在以下 3 种情形下成立: 1 ) 群落的空 间结构是随机的, 这样, 植物周围的邻居就会组成整 个群落的一个随机样本; 2) 即使在一个具有空间结 构的群落中, 如果群落中的重要相互作用发生在大 的距离上, 也就是说, 互为邻居的个体是比较大的, 那么个体的平均密度就会影响有关个体植物的许多 重要过程; 3) 个体是运动的, 这在植物中是很少发生 的。目前, 植物发生相互作用的确切尺度对植物生 
态学家来说还是空白的, 但是现有的知识表明竞争 是发生在短距离内的 (Mack \& Harper, 1977; Silander \& Pacala, 1985)。而群落的平均场假说并没有考虑 到这一点, 小尺度空间结构正好可以弥补这一缺陷, 所以我们在研究植物群落动态时应该把小尺度空间 结构和平均场假说结合起来, 只有这样才能对植物 群落动态的理论和经验框架有更深刻的理解。总 之, 小尺度空间结构的潜在影响是意义深远的, 它对 以局部空间结构为核心的植物群落动态的理论和经 验框架的发展具有重要的促进作用。

\section{参 考 文 献}

Abe S, Masaki T, Nakashizuka T (1995). Factors influencing sapling composition in canopy gaps of a temperate deciduous forest. Vegetatio, 120, 21-32.

Aston JL, Bradshaw AD (1966) . Evolution in closely adjacent plant populations. II. Agrostis stolonifera in maritime habitats. Heredi$t y, 21,649-664$.

Augspurge CK (1984). Seedling survival of tropical tree species: interactions of dispersal distance, light gaps, and pathogens. Ecology, 65, $1705-1712$.

Baldocci D, Collineau S (1994). The physical nature of solar radiation in heterogeneous canopy: spatial and temporal attributes. In: Caldwell MM, Pearcy RW eds. Exploitation of Environmental Heterogeneity by Plants. Academic Press, New York.

Barik SK, Pandey HN, Tripathi RS, Rao P (1992). Microenvironment variability and species diversity in treefall gaps in a subtropical broadleaved forest. Vegetatio, 103, 31-40.

Blackman GE (1935) . A study by statistic methods of the distribution of species in grassland association. Annals of Botany, 49, $749-777$.

Bolker BM, Pacala SW (1999). Spatial moment equations for plant competition: understanding spatial strategies and the advantages of short dispersal. The American Naturalist, 153, 575-602.

Bromley J, Brouwer J, Barker AP, Gaze S, Valentin C (1997). The role of surface water redistribution in an area of patterned vegetation in a semi-arid environment, South-West Niger. Journal of Hydrology, 198, 1 - 29.

Brooker RW, Callaghan TV (1998). The balance between positive and negative plant interactions and its relationship to environmental gradients: a model. Oikos, 81, 196-207.

Cao GX (操国兴), Zhong ZC (钟章成), Liu Y (刘芸), Xie DT (谢德体) (2003). The study of distribution pattern of Camellia rosthorniana population in Jinyun mountain. Journal of Biology (生物学杂志), 20,10-12. (in Chinese with English abstract)

Carlsson BA, Callaghan TV (1991). Positive plant interactions in tundra vegetation and the importance of shelter. Journal of Ecology, 79, $973-983$.
Chen P (陈鹏), Chu Y (初雨), Gu FX (顾峰雪), Zhang YD (张远东), Pan XL (潘晓玲) (2003). Spatial heterogeneity of vegetation and soil characteristics in oasis-desert ecotone. Chinese Journal of Applied Ecology (应用生态学报), 14, 904 908. (in Chinese with English abstract)

Chen YF (陈玉福), Yu FH (于飞海), Dong M (董鸣) (2000). Spatial heterogeneity of the psammophytic half-shrub community in Mu Us Sandland. Acta Ecologica Sinica (生态学 报), 20,568-572. (in Chinese with English abstract)

de Blois S, Domon G, Bouchard A (2002). Landscape issues in plant ecology. Ecography, 25, 244-256.

Ennos RA (2001). Inferences about spatial processes in plant populations from the analysis of molecular markers. In: Silvertown J, Antonovics J eds. Integrating Ecology and Evolution in a Spatial Context. Blackwell, Oxford, $45-73$.

Ferrière R, Le Galliard JF (2000). Invasion fitness and adaptive dynamics in spatial population models. In: Clobert J, Nichols JD, Danchin E, Dhondt A eds. Causes, Consequences and Mechanisms of Dispersal at the Individual, Population and Community Level. Oxford University Press, Oxford, UK.

Fowler N (1988). The effects of environmental heterogeneity in space and time on the regulation of population and communities. In: Davy AJ, Hutchjins MJ, Watkingson AR eds. Plant Population Ecology. Blackwell, Oxford, 36-47.

Frankland JC, Ovington JD, Marcrae C (1963). Spatial and seasonal variation in soil, litter and vegetation in some Lake District woods. Journal of Ecology, 51, 97 - 112 .

Garner W, Steinberger Y (1989). A proposed mechanism for the formation of "Fertile Island" in the desert ecosystem. Journal of Arid Environment, 16, 257 - 262.

Grei-Smith P (1987). Quantitative Plant Ecology. Butterworths, London.

Hamilton WD, May RM (1977). Dispersal in stable habitats. Nature, 269, $578-581$.

Harper JL (1977) . Population Biology of Plants. Academic press, London.

Holzapfel C, Mahall BE (1999). Bidirectional facilitation and interference between shrubs and annuls in the Mojave Desert. Ecology, 80, $1747-1761$.

Huang ZW (黄志伟), Peng M (彭敏), Chen GC (陈桂琛), Shi P (史萍), Zhou GY (周国英) (2001). The spatial distribution patterns and dynamics of some wetland dominant plants of the Qinghai Lake. Chinese Journal of Applied and Environmental Biology (应用与环境生物学报), 7, 113 - 116. (in Chinese with English abstract)

Hutchings MJ, Price ACP (1993). Does physiological integration enable clonal herbs to integrate the effects of environmental heterogeneity? Plant Species Biology, 8, 159 - 238.

Isagi Y, Kanazashi T, Suzuki W, Tanaka H, Abe T (2000). Microsatellite analysis of the regeneration process of Magnolia obavata Thumb. Heredity, 84, $143-151$. 
Jackson RB, Caldwell MM (1993). The scale of nutrient heterogeneity around individual plants and its quantification with geostatistics. Ecology, 74, 612-614.

Jeltsch F, Milton SJ, Dean WRJ, van Rooyen N (1997). Simulation pattern formation around artificial waterholes in the semiarid Kalahari. Journal of Vegetation Science, 8, 177 - 188.

Jonathan HT, Robert SN, Stanley DS (2002) . Soil resources heterogeneity in the Mojave Desert. Journal of Arid Environments, 3, $269-292$.

Kalisz S, Hanzawa FM, Tonsor SJ, Thiede DA, Voigt S (1999). Ant-mediated seed dispersal alters pattern of relatedness in a population of Trillium grandiflorum. Ecology, 80, 2620-2634.

Kellner K, Bosch OJH (1992). Influence of patch formation in determing the stocking rate for southern African grasslands. Journal of Arid Environments, 22, 99 - 105.

Kelly VR, Canham CD (1992). Resource heterogeneity in old fields. Journal of Vegetation Science, 3, 545 - 552.

Kershaw KA, Looney JH (1985) . Quantitative and Dynamic Ecology. Edward Arnold, London.

Kieft KL, White CS, Loftin SR, Aguilar R, Craig JA, Skaar DA (1998). Temporal dynamics in soil carbon and nitrogen resources at a grassland-shrubland ecotone. Ecology, 79, $671-683$.

Krahulec F, Agnew ADQ, Agnew S, Willems JH (1990). Spatial Processes in Plant Communities. Academia, Prague.

Law R, Diechmann U, Metz JAJ (2000) . Introduction. In: Dieckmann U, Law R, Metz JAJ eds. The Geometry of Ecological Interactions: Simplifying Spatial Complexity. Cambridge University Press, Cambridge, $1-6$.

Levene H (1953) . Genetic equilibrium when more than one ecological niche is available. The American Naturalist, 87, $311-313$.

Levin SA (1992). The problem of pattern and scale in ecology. Ecology, 73, 1943 - 1967.

Li GC (李贵才), He YT (何永涛), Han XG (韩兴国) (2003). Features of gaps of middle mountain moist evergreen broad-leaved forest in Ailao Mountain. Chinese Journal of Ecolo$g y$ (生态学杂志), 22, 13-17. (in Chinese with English abstract)

Liu ZG (刘振国), Li ZQ (李镇清) (2004). Fine-scale spatial pattern of Artemisia frigida population under different grazing intensities. Acta Ecologica Sinica (生态学报), 24, 227 - 234 . (in Chinese with English abstract)

Liu ZG (刘振国), Li ZQ (李镇清) (2005). Fine-scale spatial pattern of Cleistogenes squarrosa population under different grazing intensities. Acta Prataculturae Sinica (草业学报), 14, 11 17. (in Chinese with English abstract)

Liu ZM (刘志民)，Zhao XY (赵晓英)，Liu XM (刘新民) (2002) . Relationship between disturbance and vegetation. Acta Prataculturae Sinica (草业学报), 11, 1-9. (in Chinese with English abstract)

Mack RN, Harper JL (1977) . Interference in dune annuals: spatial pattern and neighbourhood effects. Journal of Ecology, 65, 345
-363 .

Mahdi A, Law R (1987). On the spatial organization of plant species in a limestone grassland. Journal of Ecology, 75, 459 476.

Molofsky J (1999) . The effect of nutrients and spacing on neighbor relations in Cardamine pensylvanica. Oikos, 84, 506 - 514.

Pacala SW, Silander JA (1990) . Field tests of neighborhood population dynamic models of two annual weed species. Ecological Monographs, 60, 113 - 134 .

Packer A, Clay K (2000). Soil pathogens and spatial patterns of seedling mortality in a temperate forest. Nature, 404, 278 281 .

Purves DW, Law R (2002). Fine-scale spatial structure in a grassland community: quantifying the plant's view. Journal of Ecology, 90, $121-129$.

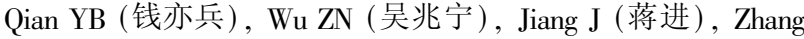
LY (张立运), Shi QD (师庆东) (2004). Impact of soil physical-chemical properties on diversity of desert plant communities diversity in agricultural development area of Kelamayi. Arid Zone Research (干旱区研究), 20 (Suppl.), 74 - 81. (in Chinese with English abstract)

Rainey PB, Travasino M (1998). Adaptive radiation in a heterogeneous environment. Nature, 394, 69-72.

Rees M, Grubb PJ, Kelly D (1996). Quantifying the impact of competition and spatial heterogeneity on the structure and dynamics of a four-species guild of winter annuals. The American Naturalist, $147,1-32$.

Schlesinger WH, Raikes JA, Hartley AE, Cross AF (1996). On the spatial pattern of soil nutrients in desert ecosystem. Ecology, $77,364-374$.

Schlesinger WH, Reynolds JF, Cunningham GL, Huenneke LF, Jarrell WM, Virginia RA, Whitford WG (1990). Biological feedbacks in global desertification. Science, 47, $1043-1048$.

Shen ZH (沈泽吴) (2002) . A multi-scale study on the vegetationenvironment relationship of a mountain forest transect. Acta Ecologica Sinica (生态学报), 22, 461 - 470. (in Chinese with English abstract)

Shen ZH (沈泽吴), Zhang XS (张新时), Jin YX (金义兴) (2000). Spatial pattern analysis and topographical interpretation of species diversity in the forests of Dalaoling in the region of the Tree Gorgaes. Acta Botanica Sinica (植物学报), 42, 620 627. (in Chinese with English abstract)

Silander JA, Pacala SW (1985). Neighborhood predictors of plant performance. Oecologia, 66, 256-263.

Silvertown J, Law R (1987). Do plants need niches? Trends in Ecology and Evolution, 2, 24-26.

Stohlgren TJ (1998) . Comparison of rangeland vegetating sampling techniques in the control grasslands. Journal of Range Management, 51, $164-172$.

Stoll P, Prati D (2001) . Intraspecific aggregation alters competitive interactions in experimental plant communities. Ecology, 82, 
$319-327$.

Stoll P, Weiner J (2000) . A neighbourhood view of interactions among individual plants. In: Diechmann U, Law R, Metz JAJ eds. The Geometry of Ecological Interactions: Simplifying Spatial Complexity. Cambridge University Press, Cambrdge, UK, 11 27.

Stowe LG, Wade MJ (1979). The detection of small-scale pattern in vegetation. Journal of Ecology, 67, 1047 - 1064 .

$\mathrm{SuZY}$ (苏志尧), Wu DR (吴大荣), Chen BG (陈北光) (2000). Structure and spatial pattern dynamics of dominant populations in a natural forest in north Guangdong Provice. Chinese Journal of Applied Ecology (应用生态学报)，11, 337 - 341 . (in Chinese with English abstract)

Thiery JM, Herbes MD, Valentin C (1995). A model simulating the genesis of banded vegetation patterns in Niger. Journal of $E$ cology, 83, $497-507$.

van Baalen M, Rand DA (1998). The unit of selection in visous populations and the evolution of altruism. Journal of Theoretical Biology, 193, $631-648$.

van der Hoeven EC, de Kroon H, During HJ (1990). Fine-scale spatial distribution of leaves and shoots of two chalk grassland perennials. Vegetatio, 86, 151-160.

van Dorp D, van den Hoek WPA, Daleboudt C (1996). Seed dispersal capacity of six perennial grassland species measured in a wind tunnel at varying wind speed and height. Canadian Journal of Botany, 74, 1956 - 1963.

van Rijnberk H, During H (1990). Bryophyte pattern and dynamics in Dutch chalk grassland. In: Krahulec F, Agnew ADQ, Agnew S, Willems JH eds. Spatial Processes in Plant Communities. Academia, Prague, $161-172$.

Wang GH (王国宏), Ren JZ (任继周), Zhang ZH (张自和) (2001) . A study on the population diversity of plant community in Hexi mountain-oasis-desert area. I . General features. Acta Prataculturae Sinica (草业学报), 10, 1-12. (in Chinese with English abstract)

Weiner J (1985). Size hierarchies in experimental populations of annual plants. Ecology, 66, $743-752$.
Weiner J (1990). Asymmetric competition in plant populations. Trends in Ecology and Evolution, 5, 360 - 364 .

Xiao DN (肖笃宁), Bu RC (布仁仓), Li XZ (李秀珍) (1997). Spatial ecology and landscape heterogeneity. Acta Ecologica Sinica (生态学报), 17, 453 - 461. (in Chinese with English abstract)

Xie JY (谢佳彦), Deng ZP (邓志平) (2003). Spatial pattern and size structure of Castanopsis castanopsis population in Wuyun Mountain. Chinese Journal of Ecology (生态学杂志), 22, 35 - 39. (in Chinese with English abstract)

Xin XP (辛晓平), Yang ZY (杨正宇), Tian XZ (田新智), Gao Q (高琼) (2000). Patch dynamics of alkaline Leymus Chinensis grassland under grazed and ungrazed conditions. Acta Phytoecologica Sinica (植物生态学报), 24,656-661. (in Chinese with English abstract)

Yang LM (杨利民), Han M (韩梅), Li JD (李建东), Zhou GS (周广胜) (2000). Impact of distribution of plant flowering phase on species diversity in grassland community. Journal of Jilin Agricultural University（吉林农业大学学报), 22, 55 58. (in Chinese with English abstract)

Yang LM (杨利民), Han M (韩梅), Zhou GS (周广胜), Wang YH (王玉辉) (2002). Studies on the maintaining mechanism of species diversity of grassland community. III . Species distribution pattern. Journal of Jilin Agricultural University (吉林农业大学 学报), 24, 58-61. (in Chinese with English abstract)

Yang LM (杨利民), Zhou GS (周广胜), Wang GH (王国宏) (2001). Investigating realized niches as a mechanism of species diversity maintenance in a species-rich grassland community. Acta Phytoecologica Sinica (植物生态学报), 25, 634-638. (in Chinese with English abstract)

Ye WH (叶万辉) (2000). The maintenance mechanism of plant community and its species diversity. Chinese Biodiversity (生物 多样性), 8, 17-24. (in Chinese with English abstract)

Zhang WG (张卫国), Huang WB (黄文冰), Yang ZY (杨振 宇) (2003). The study on the relationship between mini-patch and degradation of pasture. Acta Prataculturae Sinica (草地学 报), 12, 44-50. (in Chinese with English abstract)

责任编委: 傅伯杰 责任编辑: 姜联合,李 敏 